\title{
The Influence of Sociocultural, Environmental Factor and Aedes Larvae Density on Transmission of Dengue Hemorrhagic Fever in North Sumatera Province
}

\author{
Fazidah A Siregar ${ }^{1}$, Destanul Aulia ${ }^{2}$ \\ ${ }^{1}$ Faculty of Public Health, University of Sumatera Utara, Indonesia \\ fazidah65eyahoo.com \\ ${ }^{2}$ Department of Health Policy and Administration, University of Sumatera Utara, Indonesia \\ destanul.aulia@usu.ac.id
}

\begin{abstract}
Many factors are responsible for high incidence of dengue hemorrhagic fever (DHF). Moreover, the existence of Aedes mosquitoes plays a role in DHF transmission and larval indices was used as indicators to monitor Aedes populations. The present study determined the influence of socio-cultural, environmental factor and larvae density on DHF transmission. This study was carried out in Medan, a high incidence district and Langkat, a low incidence district. Larva survey was conducted to determine larval density. The influence of socio-cultural, environmental factors and Aedes larvae density on DHF transmission was examined by Multiple Logistic Regression. The result showed that number of family members, frequency cleaning of water container and House index (HI) were the significant factors for DHF transmission in North Sumatera Province. Sociocultural factor and larval density have been proven to significantly influence DHF transmission in North Sumatera Province. Both district have $\mathrm{HI}$ value higher than 10, which indicated have a high risk area for DHF transmission. Based on these findings, it was recommended to enhance health promotion regarding dengue prevention in the community. Furthermore, Aedes monitoring activity should be intensified to strengthen the dengue control program in North Sumatera Province.
\end{abstract}

Keywords - Socio-cultural, environmental, Aedes larvae density, dengue transmission

\section{INTRODUCTION}

Dengue hemorrhagic fever (DHF) is an important health problem in many countries around the world. Currently, more than 100 countries are endemic for dengue virus infection with 230 million dengue virus infections occur worldwide each year [1], [2], [3]. The disease has become a leading cause of hospitalization among children in several countries in Southeast Asia, and Indonesia ranked the second for DHF cases in Asia according to the World Health Organization (WHO) [4]. Based on a 2011 report by the Ministry of Health, North Sumatera Province is ranked at third highest for DHF cases in Indonesia [5]. Ever since DHF was recognized in North Sumatera in 1975, the incidence of DHF increased annually from 24/100,000 population in 2007 to $66.2 / 100,000$ population in 2015 [6].

The factors responsible for DHF incidence are complex. However, factors such as sociodemographic, behavioral, cultural and environmental factors are contributing to DHF incidence. The environment affects the Aedes mosquito breeding sites and furthermore, the existence of Aedes mosquitoes plays a role in disease transmission [7].

Several studies investigated the factors contribute to DHF incidence. Siqueira et al. (2004), found that older age, low education and low income are significantly associated with dengue fever incidence. Thammapalao et al. (2008) in Southern Thailand found that high population density, pattern and house structure such as shop houses, brick houses are major risk factors for DHF incidence. Phuong et al. (2008), found that occupation (farmer), number of children less than 15 years old in households, lack of experience with dengue fever in households, presence of a garden near the house and presence of water containers with mosquito larvae are associated with a higher risk of dengue fever in Vietnam [8], [9], [10]. On the other hand, Mondini and Neto (2007) found presence of solid around the household and prolonged storage of water for domestic use can create potential breeding grounds for Aedes aegypti, thereby increasing the transmission of dengue 
infections [11]. Spiegel et al. (2007) investigated the association of social and environmental factors with the presence of Aedes aegypti and found a higher risk for DHF incidence [12].

Moreover, the existence of Aedes mosquitoes plays a role in disease transmission. Larval indices, which have been used to quantify vector breeding sites and function as indicators to monitor Aedes populations for dengue virus transmission, include the Container Index (CI), House Index (HI) and Breteau Index (BI) [13], [14], [15].

DHF is a major health problem in North Sumatera Province and despite major prevention efforts have been done, the incidence of DHF remains high. Aedes mosquito is the main vector that plays a role in disease transmission. For effective control measures to break the chain of transmission and reduce the incidence of DHF, efforts should be concentrated on vector eradication and the disease risk factors, particularly those risk factors related to social-cultural and environmental conditions that contribute to DHF incidence. Therefore, the present study was designed to identify the social-cultural and environmental determinants of dengue infections.

\section{MATERIALS AND METHODS}

This study was carried out in Medan, a district with high DHF incidence and Langkat, a district with low DHF incidence, in North Sumatera province from April, 2011 to May, 2011. For each selected house, the socio-cultural and environmental data were collected by interview using questionnaires that were developed based on questionnaires published research. On the other hand, a larval survey was conducted based on WHO procedure and involved the examination of both indoor and outdoor water containers to look for the presence of Aedes larvae. For each positive container, a larva was pipetted into a plastic cup or plastic bag and brought back to the laboratory for identification. The House Index (HI), Container Index (CI) and Breteau Index (BI) were calculated to determine the larval density.

\section{A. Sample}

The study population was households in both districts with high DHF incidence (HIDs) and low DHF incidence (LIDs). Multistage sampling was used to select the study population. In the first stage, one district with high DHF incidence and one district with low DHF incidence were purposively selected based on the incidence of DHF in the previous year. Medan, a district with high DHF incidence and Langkat, a district with low DHF incidence, in the North Sumatera province were ultimately the two districts selected for this study (Fig.1). In the second stage, two sub districts, one with the highest and the other with the lowest DHF cases were again purposively selected for each district. In the third stage, the same criteria as above were applied to select two villages from the sub districts. For each village, two sub-villages were randomly selected. In the sub district with high DHF cases, households were systematically selected among the households with reported cases from the health office registry, whereas, in the low sub district, households were selected using systematic sampling based on the registry of the household from the sub-district administrative office.

\section{B. Sample Size}

The sample size for this study was calculated using the two-proportion formula [16] with an average proportion of DHF cases in the three districts with high DHF cases (P1) of 0.156 and an average proportion of DHF cases in the three districts with low DHF cases (P0) of 0.017 with an allowable error of $5 \%$ and a power of study of $80 \%$. Multistage sampling was applied in this study and the sample size was multiplied by the design effect of 2 . Therefore, 304 households for districts with both high and low DHF cases were included in this study.

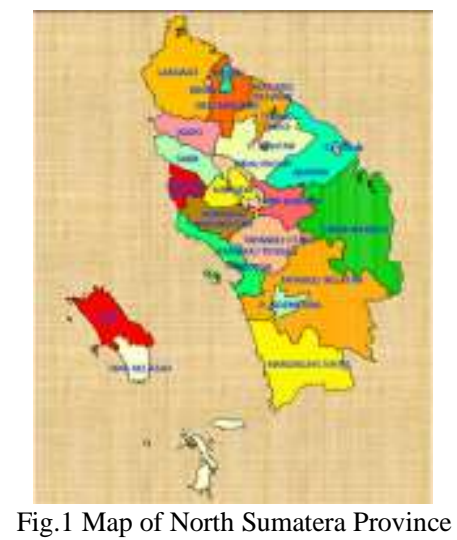

\section{Study Instruments}

The socio-cultural data were collected using interviews and recorded using questionnaires. The 
socio-cultural factors included age, sex, education, occupation, number of family members, frequency cleaning of water container, frequency cleaning of garbage collection and frequency cleaning of tray refrigerator. The housing density was expressed as the average number of persons per household. The cut-off point was 4 persons per household. The environmental factors included house materials, house style, door and window screen gutter and container with Aedes larvae.The larval survey was conducted to determine larval density. The tools used included a survey form, pipettes, plastic bottles, plastic bags, a specimen vial with stoppers, pens, a label and a flashlight. All of the indoor and outdoor containers at the selected houses were inspected to look for the presence of Aedes larvae. From each positive container, a larva was pipetted into a plastic cup or plastic bag and brought back to the laboratory for identification and then the findings were recorded on the survey form. Three larval indices, the House Index (HI), Container Index (CI) and Breteau Index (BI) were calculated. The $\mathrm{HI}$ is defined as the percentage of houses positive for Aedes larvae. The $\mathrm{CI}$ is defined as the percentage of containers positive for Aedes larvae. BI is defined as the number of containers positive for Aedes larvae per 100 houses examined.

\section{Statistical Analysis}

The Statistical Package for Social Science (SPSS) program was used for data analysis. The sociocultural information of the respondents as well as environmental information and larval Aedes indices were calculated and tabulated for descriptive statistics. The influence of socio-cultural, environmental factors and Aedes larvae density on DHF transmission was examined using multiple logistic regression. Initially, the data were analyzed using simple logistic regression to select the significant variables with $\mathrm{p}$-values less than 0.25 . Then, the significant variables were included in a multiple logistic regression.

\section{RESULTS}

The majority of respondents both in HIDs and LIDs were 39-41 years old, however the mean age of respondents in HIDs was higher than LIDs. Most of them had low education, were not working and were members of households that had more than 4 family members. Habits that promote Aedes aegypti breeding, such as frequency of cleaning water containers, within more than 15 days in HIDs was higher than LIDs. Whereas frequency of cleaning garbage disposal and frequency of cleaning tray refrigerator both in HIDs and LIDs within 1-7 days and within 1-4 days, respectively (Table1).

Concrete houses with interconnection style were the most common houses in both HIDs and LIDs. Moreover, most of houses both in HIDs and LIDs did not have screened door, window and gutter. On the other hand, positive container was more common in HIDs than LIDs (Table 2).

The results of our simple logistic regression revealed that significant variables with p-values less than 0.25: age, education, occupation, number of family member, frequency of cleaning water container, house style, house with gutter and positive container with larvae (Table 3 ). These variables then were included in the multiple logistic regression and the result as presented in Table 4 .

TABLE I

SOCIO-CUlTURAL CHARACTERISTICS OF RESPONDENTS IN HIGH AND LOW INCIDENCE DISTRICTS FOR DHF IN NORTH SUMATERA PROVINCE

\begin{tabular}{|c|c|c|}
\hline Variable & $\begin{array}{l}\text { HIDs } \\
\text { n }(\%)\end{array}$ & $\begin{array}{l}\text { LIDs } \\
\text { n }(\%)\end{array}$ \\
\hline Age (year) ${ }^{\mathrm{a}}$ & $41.7(10.1)$ & $39.1(9.5)$ \\
\hline Sex & & \\
\hline Female & $149(98.0)$ & $151(99.3)$ \\
\hline Male & $3(2.0)$ & $1(0.7)$ \\
\hline \multicolumn{3}{|l|}{ Education } \\
\hline High & $57(37.5)$ & $47(30.9)$ \\
\hline Low & $95(62.5)$ & $105(69.1)$ \\
\hline \multicolumn{3}{|l|}{ Occupation } \\
\hline Not working & $97(63.8)$ & $107(70.4)$ \\
\hline Working & $55(36.2)$ & $45(29.6)$ \\
\hline \multicolumn{3}{|l|}{ Number of family members } \\
\hline$<4$ person & $25(16.4)$ & $39(25.7)$ \\
\hline$\geq 4$ person & $127(83.6)$ & $113(74.3)$ \\
\hline \multicolumn{3}{|l|}{$\begin{array}{l}\text { Frequency cleaning of water } \\
\text { container }\end{array}$} \\
\hline Unused/ 1-4 days & $92(60.5)$ & $122(80.3)$ \\
\hline 5-15 days & $37(24.4)$ & $21(13.8)$ \\
\hline$>15$ days & $23(15.1)$ & $9(5.9)$ \\
\hline \multicolumn{3}{|l|}{$\begin{array}{l}\text { Frequency cleaning of } \\
\text { garbage collection }\end{array}$} \\
\hline Unused & $35(23.0)$ & $44(28.9)$ \\
\hline 1-7 days & $112(73.7)$ & $108(71.1)$ \\
\hline More than a week & $5(3.3)$ & $0(0.0)$ \\
\hline \multicolumn{3}{|l|}{$\begin{array}{l}\text { Frequency cleaning tray of } \\
\text { refrigerator }\end{array}$} \\
\hline Unused/ 1-4 days & $105(68.1)$ & $99(65.2)$ \\
\hline 5-15 days & $25(16.4)$ & $29(19.0)$ \\
\hline More 15 days & $22(14.5)$ & $24(15.8)$ \\
\hline
\end{tabular}

a: mean (SD) 
TABLE II

ENVIRONMENTAL CHARACTERISTICS OF RESPONDENTS IN HIGH AND LOW INCIDENCE DISTRICTS FOR DHF IN NORTH SUMATERA PROVINCE

\begin{tabular}{|l|l|l|}
\hline Variable & $\begin{array}{l}\text { HIDs } \\
\mathbf{n}(\%)\end{array}$ & $\begin{array}{l}\text { LIDs } \\
\mathbf{n}(\%)\end{array}$ \\
\hline House Material & $8(5.3)$ & $10(6.6)$ \\
Wood & $53(34.9)$ & $35(23.0)$ \\
Brick & $57(37.5)$ & $71(46.7)$ \\
Concrete & $34(22.4)$ & $35(23.0)$ \\
Mixed & $0(0.0)$ & $1(0.7)$ \\
Others & & \\
\hline House Style & $54(35.5)$ & $75(49.3)$ \\
Independent house & $96(63.2)$ & $77(50.7)$ \\
Interconnection house & $1(0.7)$ & $0(0.0)$ \\
Slum house & $1(0.7)$ & $0(0.0)$ \\
Semi pucca & & $19(12.5)$ \\
\hline Door with Screen & $22(14.5)$ & $133(87.5)$ \\
Yes & $130(85.5)$ & $22(14.5)$ \\
No & & $130(85.5)$ \\
\hline Window with Screen & $26(17.1)$ & $13(8.6)$ \\
Yes & $126(82.9)$ & $139(91.4)$ \\
No & & \\
\hline Use Gutter & $20(13.2)$ & $50(7.1)$ \\
Yes & $132(86.8)$ & $527(92.9)$ \\
No & & \\
\hline Container & $65(12.6)$ & \\
Positive & $452(87.4)$ & \\
Negative & & \\
\hline
\end{tabular}

TABLE III

SOCIO-CULTURAL AND ENVIRONMENTAL FACTORS ASSOCIATED WITH DENGUE HEMORRHAGIC FEVER TRANSMISSION IN NORTH SUMATERA PROVINCE BY SIMPLE LOGISTIC REGRESSION

\begin{tabular}{|c|c|c|c|c|}
\hline Variable & $\begin{array}{l}\text { HIDs } \\
\text { n(\%) }\end{array}$ & $\begin{array}{l}\text { LIDs } \\
\text { n(\%) }\end{array}$ & $\begin{array}{l}\text { Crude OR } \\
(95 \% \text { CI })\end{array}$ & $\begin{array}{l}\text { p value } \\
\text { of Wald } \\
\text { statistics }\end{array}$ \\
\hline Age(year) ${ }^{\mathrm{a}}$ & $\begin{array}{l}41.7 \\
(10.1)\end{array}$ & $\begin{array}{l}39.1 \\
(9.5) \\
\end{array}$ & $\begin{array}{c}1.03 \\
(1.00,1.05)\end{array}$ & 0.024 \\
\hline $\begin{array}{l}\text { Education } \\
\text { High } \\
\text { Low }\end{array}$ & $\begin{array}{l}57(37.5) \\
95(62.5)\end{array}$ & $\begin{array}{l}47(30.9) \\
105(69.1)\end{array}$ & $\begin{array}{c}0.75 \\
(0.46,1.20)\end{array}$ & 0.227 \\
\hline $\begin{array}{l}\text { Occupation } \\
\text { Not working } \\
\text { Working }\end{array}$ & $\begin{array}{l}97(63.8) \\
55(36.2)\end{array}$ & $\begin{array}{l}107(70.4) \\
45(29.6)\end{array}$ & $\begin{array}{r}1.35 \\
(0.83,2.18)\end{array}$ & 0.223 \\
\hline $\begin{array}{l}\text { Number family } \\
\text { member } \\
<4 \text { person } \\
\geq 4 \text { person }\end{array}$ & $\begin{array}{l}25(16.4) \\
127(83.6)\end{array}$ & $\begin{array}{l}39(25.7) \\
113(74.3)\end{array}$ & $\begin{array}{c}1.75 \\
(0.99,3.08)\end{array}$ & 0.050 \\
\hline 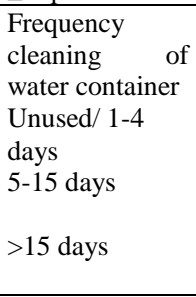 & $\begin{array}{l}92(60.5) \\
37(24.4) \\
23(15.1)\end{array}$ & $\begin{array}{l}122(80.3) \\
21(13.8) \\
9(5.9)\end{array}$ & $\begin{array}{c}2.34 \\
(1.28,4.26) \\
3.39 \\
(1.49,7.57) \\
\end{array}$ & $\begin{array}{l}0.001 \\
0.006 \\
0.003\end{array}$ \\
\hline $\begin{array}{l}\text { Use Gutter } \\
\text { Yes } \\
\text { No }\end{array}$ & $\begin{array}{l}20(13.2) \\
132(86.8)\end{array}$ & $\begin{array}{l}13(8.6) \\
139(91.4)\end{array}$ & $\begin{array}{c}0.62 \\
(0.29,1.30)\end{array}$ & 0.200 \\
\hline $\begin{array}{c}\text { Container } \\
\text { Positive } \\
\text { Negative }\end{array}$ & $\begin{array}{l}65(12.6) \\
452(87.4)\end{array}$ & $\begin{array}{l}40(7.1) \\
527(92.9)\end{array}$ & $\begin{array}{c}1.53 \\
(1.05,2.23)\end{array}$ & 0.027 \\
\hline
\end{tabular}

\begin{tabular}{|c|c|c|c|c|c|c|}
\hline & \multicolumn{3}{|c|}{ High incidence district } & \multicolumn{3}{|c|}{ Low incidence district } \\
\hline & Aedesspp & $\begin{array}{c}\text { Ae. } \\
\text { aegypti }\end{array}$ & \begin{tabular}{|c|} 
Ae. \\
albopictus
\end{tabular} & Aedesspp & $\begin{array}{c}\text { Ae. } \\
\text { egypti }\end{array}$ & $\begin{array}{c}\text { Ae. } \\
\text { albopictus }\end{array}$ \\
\hline $\begin{array}{l}\text { Number of } \\
\text { households } \\
\end{array}$ & 152 & 152 & 152 & 152 & 152 & 152 \\
\hline \begin{tabular}{|l} 
Number of \\
positive \\
households \\
\end{tabular} & 55 & 50 & 5 & 33 & 16 & 19 \\
\hline $\begin{array}{l}\text { Number of } \\
\text { containers }\end{array}$ & 519 & 519 & 519 & 594 & 594 & 594 \\
\hline $\begin{array}{l}\text { Number of } \\
\text { positive containers }\end{array}$ & 65 & 60 & 5 & 45 & 14 & 28 \\
\hline \multicolumn{7}{|l|}{ Larval index } \\
\hline $\mathrm{HI}$ & 35.0 & 33.0 & 3.0 & 22.0 & 11.0 & 13.0 \\
\hline CI & 13.0 & 12.0 & 1.0 & 8.0 & 2.0 & 5.0 \\
\hline $\mathrm{BI}$ & 43.0 & 39.0 & 3.0 & 30.0 & 9.0 & 18.0 \\
\hline
\end{tabular}

Moreover, the larval indices (HI, CI and BI) were analyzed to determine the factors associated with

SOCIO-CULTURAL AND ENVIRONMENTAL FACTORS ASSOCIATED WITH DENGUE HEMORRHAGIC FEVER TRANSMISSION IN NORTH SUMATERA PROVINCE BY MULTIPLE LOGISTIC REGRESSION.

\begin{tabular}{|l|c|c|c|c|}
\hline Variable & $\begin{array}{c}\text { HIDs } \\
\mathbf{n}(\%)\end{array}$ & $\begin{array}{c}\text { LIDs } \\
\mathbf{n}(\%)\end{array}$ & $\begin{array}{c}\text { Adjusted OR } \\
(\mathbf{9 5} \% \text { CI })\end{array}$ & $\begin{array}{c}\mathbf{p} \\
\text { value }\end{array}$ \\
\hline $\begin{array}{l}\text { Number family } \\
\text { member } \\
\text { < 4 person }\end{array}$ & $25(16.4)$ & $39(25.7)$ & & \\
$\quad \geq 4$ person & $127(83.6)$ & $113(74.3)$ & $1.83(1.02,3.28)$ & 0.043 \\
\hline $\begin{array}{l}\text { Frequency cleaning } \\
\text { of water container }\end{array}$ & & & & \\
Unused/ 1-4 days & $92(60.5)$ & $122(80.3)$ & & \\
5-15 days & $37(24.4)$ & $21(13.8)$ & $2.46(1.33,4.54)$ & 0.004 \\
$>15$ days & $23(15.1)$ & $9(5.9)$ & $3.55(1.54,8.17)$ & 0.003 \\
\hline
\end{tabular}

Forward LR Multiple Logistic Regression was applied. There was no interactionand multicolinearityHosmerLemeshow test $(\mathrm{p}=0.014)$. Classification table (overall correctly classified percentage $=61.8$ ) Area under the ROC curve $(64.5 \%)$ were applied to check the model fitness.

Aedesa aegypti and Aedes albopictus were found in both high and low incidence district in 11 and 12 type of water container, respectively. Aedes aegypti larvae were predominantly found in Medan, whereas, Aedes albopictus larvae were predominantly found in Langkat. The larval indices (HI, CI and $\mathrm{BI}$ ) for Aedes aegypti were higher in Medan than in Langkat (33, 12 and 39 and 11,2 and 9 , respectively), whereas, the larval indices (HI, CI and $\mathrm{BI}$ ) for Aedes albopictus were higher in Langkat than in Medan (Table 5).

TABLE V

AEDES LARVAE INDICES IN DISTRICTS WITH HIGH AND LOW DHF IN NORTH SUMATERA PROVINC anazed to determine the factors associated with 
DHF transmission and the results revealed that House Index (HI) was a determinant of DHF transmission in North Sumatera province. Houses with Aedes larvae had 1.093 times odds for DHF transmission compared to houses without larvae (Table 6). Based on WHO standard, both district had HI higher than $10 \%$, means that both districts had a high risk of DHF transmission.

TABLE VI

ASSOCIATION BETWEEN VECTOR INDICES AND DENGUE HEMORRHAGIC Fever Transmission in North Sumatera Province Using Multiple LOGISTIC REGRESSION.

\begin{tabular}{|l|c|c|c|c|}
\hline Variable & $\begin{array}{c}\text { HIDs } \\
\mathbf{n}(\%)\end{array}$ & $\begin{array}{c}\text { LIDs } \\
\mathbf{n}(\%)\end{array}$ & $\begin{array}{c}\text { Adjusted OR } \\
\mathbf{( 9 5} \% \mathbf{C I})\end{array}$ & p value \\
\hline $\begin{array}{l}\text { House } \\
\text { indices } \\
\text { House (+) }\end{array}$ & $54(35.5)$ & $29(19.1)$ & $\begin{array}{c}1.09 \\
(3.04,3.94)\end{array}$ & 0.001 \\
House (-) & $98(64.5)$ & $123(80.9)$ & & \\
\hline
\end{tabular}

Forward LR Multiple Logistic Regression was applied. There was no interaction or multicollinearity. Classification table (overall correctly classified percentage $=58.2$ ) An area under the ROC curve $(58.2 \%)$ was applied to check the model fitness.

\section{DISCUSSION}

Thus far, there is no vaccine or specific medication for dengue hemorrhagic fever and transmission of DHF is directly related to its vector. Therefore, vector control has been the right choice for the prevention and control of dengue hemorrhagic fever. Furthermore, for effective control measures, efforts should be focused on monitoring distribution of vector and the risk factors that promote potential breeding places for Aedes vector including sociocultural and environmental factors.

In the present study, number of family members, frequency cleaning of water container and House index were the significant factor for DHF transmission in North Sumatera Province. Housing density was a determinant factor for DHF which could facilitate dengue transmission. Similar findings were reported by Koyadun et al. (2012) who found that household family members of more than 4 persons was associated with DHF transmission [17].

Aedes aegypti usually breeds in water containers which have not been emptied and cleaned for a long time. Frequency cleaning the containers more than 8 days (larvae stage), may increase the number of adult Aedes, thereby increasing risk of dengue transmission. In the present study, frequency of cleaning water container more than 15 days in HIDs was higher than in LIDs. Moreover, container having larvae in HIDs was higher than LIDs. Frequency of cleaning water container in longer time resulted in the water container having Aedes larvae, thereby, increasing risk for DHF transmission. This finding was similar to the study by Bohra \& Andrianasolo (2001) in endemic area of Jalore in Rajasthan state India. They found that the frequency of cleaning water container once in more than 8 days contributed to the abundance of adult mosquitoes and the risk of dengue transmission [18].

Larval survey was conducted to determine the larval density and monitor distribution and vector abundance. The HI, CI and BI were used to help stratify the DHF risk areas. In this study, Aedes aegypti larval indices (HI, CI, BI) were higher in HIDs than in LIDs. Larval indices (HI, CI and BI) for Aedes larvae in both HIDs and LIDs were 35, 13 and 43 and 22, 8 and 34, respectively. Moreover, larva indices was significantly associated with DHF transmission and furthermore, the house index was found to be an indicator of DHF transmission in North Sumatera province. Our study revealed that both HIDs and LIDs had HI greater than 10, which means both districts have a high risk for DHF transmission. Pham et al.(2011) in Dak Lak Province in The central highlands region of Vietnam found that the incidence of DHF was significantly associated with House indices, container indices and Breteau indices. Promprou study in Thailand, which found that both high and low risk DHF areas had a high risk of DHF transmission.

\section{CONCLUSION}

Our study revealed that socio-cultural factor and larval density have been proven to significantly influence DHF transmission in North Sumatera Province. Moreover, the larval indices (HI, CI and BI) for A. aegypti were higher in HIDs than in LIDs. Both high and low incidence districts had HI greater than 10 , which indicated both districts have a high risk of DHF transmission. For effective control strategies for DHF, the efforts should be focused on 
distribution of vectors and disease risk factor. It was recommended to enhance health promotion regarding dengue prevention in the community and intensified Aedes monitoring activity to strengthen the dengue control program in North Sumatera Province.

\section{ACKNOWLEDGMENTS}

We are grateful to the head of the health facility for their assistance in this study. We are also thankful to all of the participants and people who were involved in this study. No conflict of interest.

\section{REFERENCES}

[1] Guzman, A. \& Istúriz, R. E. Update on the global spread of dengue International journal of antimicrobial agents, 36, S40-S42,2010.

[2] Guzman, M. G., Halstead, S. B., Artsob, H., Buchy, P., Farrar, J., Gubler, D. J., Hunsperger, E., Kroeger, A., Margolis, H. S., Martinez, E., Nathan M. B., Pelegrino, J. L., Simmons, C., Yoksan, S. \& Peeling, R. W. Dengue: a continuing global threat. Nat Rev Microbiol, 8(12 Suppl), S716,2010 .

[3] Wilder-Smith, A., Renhorn, K. E., Tissera, H., Abu Bakar, S., Alphey, L., Kittayapong, P., Lindsay, S., Logan, J., Hatz, C., Reiter, P., Rocklov, J., Byass, P., Louis, V. R., Tozan, Y., Massad, E., Tenorio, A., Lagneau, C., L'Ambert, G., Brooks, D., Wegerdt, J. \&Gubler, D. DengueTools: innovative tools and strategies for the surveillance and control of dengue. Glob Health Action, 5,2012.

[4] Ministry of Health of Indonesia. Report of dengue hemorrhagic cases in Indonesia.Jakarta, 2010.

[5] MHI., 2011. Report of dengue hemorrhagic cases in Indonesia Ministry of Health of Indonesia (MHI), Jakarta, Indonesia.

[6] MHI., 2015. Report of dengue hemorrhagic cases in NorthSumateraProvince. Ministry of Health of Indonesia (MHI) Jakarta Indonesia.

[7] Thavara, U., A. Tawatsin and J. Chompoosri, 2004. Evaluation of attractants and egg-laying substrate preference foroviposition by Aedesalbopictus (Diptera: Culicidae). J. VectorEcol., 29: 66-72.

[8] Siqueira, J.B., C.M. Martelli, I.J. Maciel, R.M. Oliveira and M.G. Ribeiroet al., 2004. Household survey of dengue infection in central Brazil: Spatial point pattern analysis and risk factors assessment. Am. J. Trop. Med. Hygiene, 71: 646-651. Spiegel, J.M., M. Bonet, A.M. Ibarra, N. Pagliccia, V. Ouellette.

[9] Thammapalo, S., V. Chongsuvivatwong, A. Geater and M. Dueravee, 2008. Environmental factors and incidence of dengue fever and dengue haemorrhagic fever in an urban area, Southern Thailand.Epidemiol.Infect., 136: 135-143.

[10] Phuong, H.L., P. de Vries, C. Boonshuyar, T.Q. Binh, N.V. Nam and P.A. Kager, 2008. Dengue risk factors and community participation in binhthuan province, vietnam, a household survey. Southeast Asian J. Trop. Med. Public Health, 39: 79-89.

[11] Mondini, A. and F.C. Neto, 2007. Socioeconomic variables and dengue transmission.Revista de SaudePublica, 41: 923-993.

[12] Spiegel, J.M., M. Bonet, A.M. Ibarra, N. Pagliccia, V. Ouellette and A. Yassi, 2007. Social andenvironmental determinants of Aedesaegypti infestation in Central Havana: Results of a case-control study nested in an integrated dengue surveillance programme in Cuba. Trop. Med. Int Health, 12: 503-510.

[13] Sanchez, L., V. Vanlerberghe, L. Alfonzo, M.D.C. Marquetti,M.G. Guzman, J. Bisset and P. van der Stuyft, 2006. Aedesaegypti larval indices and risk for dengue epidemics.Emerging Infect. Dis., 12: 800806.

[14] Abdalmagid, M.A. and S. Alhusein, 2008. Entomological investigation of Aedesaegypti in Kassala and Elgadarief States, Sudan. Sudanese J. Public Health, 3: 77-80.

[15] Erlanger, T.E., J. Keiser and J. Utzinger, 2008. Effect of dengue vector control interventions on entomological parameters in developing countries: A systematic review and meta-analysis. Med. Vet. Entomol. 22: 203-221.

[16] Naing, N.N., 2010. A Practical Guide on Determination ofSample Size in Health Sciences Research.PustakaAman Press,Malaysia.

[17] Koyadun, S., Butraporn, P. \& Kittayapong, P. (2012). Ecologic and sociodemographic risk determinants for dengue transmission in urban areas in Thailand. Interdisciplinary Perspectives on Infectious Diseases, 2012,1-12.

[18] Bohra, A. \& Andrianasolo, H. (2001). Application of GIS in modeling of dengue risk based on sociocultural data: case of Jalore, Rajasthan, India. Dengue Bulletin, 25, 92-102.

[19] Pham, H. V., Doan, H. T., Phan, T. T. \& Minh, N. N. T. (2011) Ecological factors associated with dengue fever in a central highlands Province, Vietnam. BioMed CentralInfectious Diseases, 11(1), 172,1-6.

[20] Promprou, S., Jaroensutasinee, M. \& Jaroensutasinee, K. (2005). Climatic Factors Affecting Dengue Hemorrhagic Fever Incidence in Southern ThailandDengue Bulletin, 29, 41-48. 